\title{
Usposabljanje mladih raziskovalcev
}

UDK: 378:001.891

\author{
Tanja Cvek \\ Inštitut za računovodstvo, Brezovica pri Ljubljani \\ tanja.cvek @ iracunovodstvo.eu
}

\begin{abstract}
IZVLEČEK
Eden od instrumentov znanstvene politike Javne agencije za raziskovalno dejavnost Republike Slovenije (ARRS) je financiranje podiplomskega študija in raziskovalnega usposabljanja mladih raziskovalcev. Od leta 1985 zelo uspešno poteka program, imenovan Projekt 2000 mladih raziskovalcev, in prav zaradi uspešnosti tega programa ARRS namenja financiranju usposabljanja kadrov precejšen del svojih proračunskih sredstev. Za program mladih raziskovalcev je značilno, da so mladi raziskovalci ob podiplomskem študiju vključeni v raziskovalno delo na temeljnih ali razvojno raziskovalnih aplikativnih projektih in so $v$ rednem delovnem razmerju za določen čas. ARRS zagotavlja sredstva za njihove plače, prispevke, materialne in nematerialne stroške za raziskovalno delo ter podiplomski študij. Sredstva za usposabljanje mladih raziskovalcev se dodelijo za določen čas, in sicer za doktorat znanosti do največ štiri leta in šest mesecev. Namen raziskave je bil prikazati vidik usposabljanja, kakršnega vidijo mladi raziskovalci. Predvsem nas je zanimalo, s čim so najbolj nezadovoljni, kaj jim še posebej povzroča skrbi in kje vidijo prednosti ter pomanjkljivosti tovrstnega usposabljanja.
\end{abstract}

Ključne besede: mladi raziskovalec, mentor, usposabljanje, raziskovalna skupina, doktorat, zaposlitev

\section{Uvod}

Javna agencija za raziskovalno dejavnost Republike Slovenije (ARRS) opravlja strokovne, razvojne in izvršilne naloge $v$ zvezi z izvajanjem sprejetega Nacionalnega raziskovalnega in razvojnega programa $\vee$ okviru veljavnega proračunskega memoranduma in državnega proračuna, ter druge naloge pospeševanja raziskovalne dejavnosti, skladno z namenom ustanovitve. Njena naloga je tudi skrb za izvedbo programa mladih raziskovalcev, ki ga izvaja $v$ skladu z 
Nacionalnim raziskovalnim in razvojnim programom ter letno politiko ministrstva, pristojnega za znanost - Ministrstva za visoko šolstvo, znanost in tehnologijo.

Eden od instrumentov znanstvene politike ARRS je financiranje podiplomskega študija in raziskovalnega usposabljanja mladih raziskovalcev. Program Projekt 2000 mladih raziskovalcev zelo uspešno poteka že od leta 1985 in je izdatno prispeval $\mathrm{k}$ dvigu raziskav in $\mathrm{h}$ kadrovskemu pomlajevanju raziskovalnih skupin. Zaradi uspešnosti tega programa agencija namenja financiranju usposabljanja kadrov precejšen del svojih proračunskih sredstev. Do leta 2006 je bilo v program vključenih 5.347 mladih raziskovalcev.

Za program mladih raziskovalcev je značilno, da se mladi raziskovalci ob podiplomskem študiju vključujejo $v$ raziskovalno delo pri temeljnih ali razvojno raziskovalnih aplikativnih projektih in so $v$ rednem delovnem razmerju za določen čas. ARRS zagotavlja sredstva za njihove plače, prispevke, materialne in nematerialne stroške za raziskovalno delo ter podiplomski študij. Sredstva za usposabljanje mladih raziskovalcev se dodeljujejo za določen čas, in sicer za doktorat znanosti do največ štiri leta in šest mesecev. $V$ povprečju znaša letno financiranje enega mladega raziskovalca 27,500 EUR. Vsako leto pa usposabljanje zaključi od 200 do 250 mladih raziskovalcev. Nacionalni raziskovalni programi so vedno poudarjali vzgojo raziskovalnih kadrov kot komplementarni cilj raziskovalne dejavnosti ter $\vee$ zvezi s tem poudarjali, da "zaradi majhnosti in relativne nerazvitosti Slovenija ne more sama ustvarjati vsega znanja, ki ga potrebuje, zato je še posebej pomembna skrb za širjenje $v$ tujini nastalega znanja, kar pa nikakor ne pomeni, da bi bilo za Slovenijo primerneje, da zapostavi temeljno raziskovanje $v$ korist prenosa znanja, saj je ustvarjanje novega znanja pogoj za uspešno prenašanje znanja". Namen raziskave je bil prikazati vidik usposabljanja, kakršnega vidijo mladi raziskovalci. Predvsem nas je zanimalo, s čim so najbolj nezadovoljni, kaj jim še posebej povzroča skrbi in kje vidijo prednosti ter pomanjkljivosti tovrstnega usposabljanja.

\section{Izhodišča za raziskavo}

Koncept usposabljanja mladih raziskovalcev $v$ raziskovalnih skupinah se vsa leta ne spreminja. Od skupin se pričakuje timsko delo, kar je pri usposabljanju mladih raziskovalcev še posebej pomembno. Odgovornost za izvajanje programa uposabljanja prevzamejo mentor, vodja raziskovalne skupine in mladi raziskovalec. 
ARRS o usposabljanju mladega raziskovalca sklene pogodbo z izvajalcem usposabljanja (visokošolsko organizacijo ali raziskovalnim inštitutom) in z mladim raziskovalcem. $V$ raziskovalnih skupinah se mladi raziskovalci ob študiju raziskovalno usposabljajo na temeljnih, aplikativnih in razvojnih raziskavah. Vodje in mentorji v raziskovalnih skupinah, kjer se mladi raziskovalci usposabljajo, naj bi se posluževali tudi možnosti pošiljanja mladih raziskovalcev na krajša usposabljanja na univerze in inštitute $\vee$ tujino, $v$ funkciji kakovostnejšega usposabljanja mladega raziskovalca, kot tudi večje odprtosti raziskovalne skupine $v$ svet. Pogosto se $v$ različne razprave o usposabljanju vključujejo tudi mladi raziskovalci, ki pri tem opozarjajo na neustrezne rešitve pri nastavitvah mladih raziskovalcev na univerzah in $v$ raziskovalnih organizacijah, pomanjkljivosti pri samem usposabljanju in težave po končanem usposabljanju.

\section{Delovna metoda}

Za ugotavljanje zadovoljstva mladih raziskovalcev pri njihovem usposabljanju je bila izvedena anketa med mladimi raziskovalci s treh visokošolskih zavodov in z dveh raziskovalnih inštitutov. Od 70 vprašalnikov, ki so bili posredovani mladim raziskovalcem, je bilo pridobljenih 61 izpolnjenih, kar je nekaj več kot $87 \%$ od vseh razdeljenih vprašalnikov. Da bi dobili še verodostojnejši prikaz uspešnosti usposabljanja mladih raziskovalcev, so bili s 16 mentorji mladih raziskovalcev opravljeni intervjuji. Odgovori so bili obdelani v programu Excel in izdelane grafične predstavitve, z željo, da bi bilo predstavljeno karseda natančno dejansko stanje glede usposabljanja, kakršnega vidijo prav mladi raziskovalci sami in nekateri njihovi mentorji.

\section{Predstavitev rezultatov raziskave}

Mladi raziskovalci, ki končajo usposabljanje, ostanejo zaposleni v raziskovalnih organizacijah za obnovo raziskovalnega kadra ali v visokošolskih organizacijah za obnovo raziskovalno-pedagoškega kadra. Nekateri se vključijo v organizacije s področja gospodarstva, spet drugi se zaposlijo $v$ državni upravi.

Poleg podatkov o želeni zaposlitvi po končanem študiju, stikih z raziskovalno skupino, v kateri se usposabljajo, smo želeli pridobiti tudi podatke o prednostih in 
slabostih trenutnega usposabljanja. Eden glavnih razlogov za izvedbo ankete je bil ugotoviti, kakšne so slabosti usposabljanja mladih raziskovalcev.

$\checkmark$ posredovanem vprašalniku nas je uvodoma zanimalo, kakšen je bil razlog, da so se mladi raziskovalci odločili za to vrsto študija. Dobili smo naslednjo strukturo:

\section{Slika 1: Razlog za študij kot mladi raziskovalec}

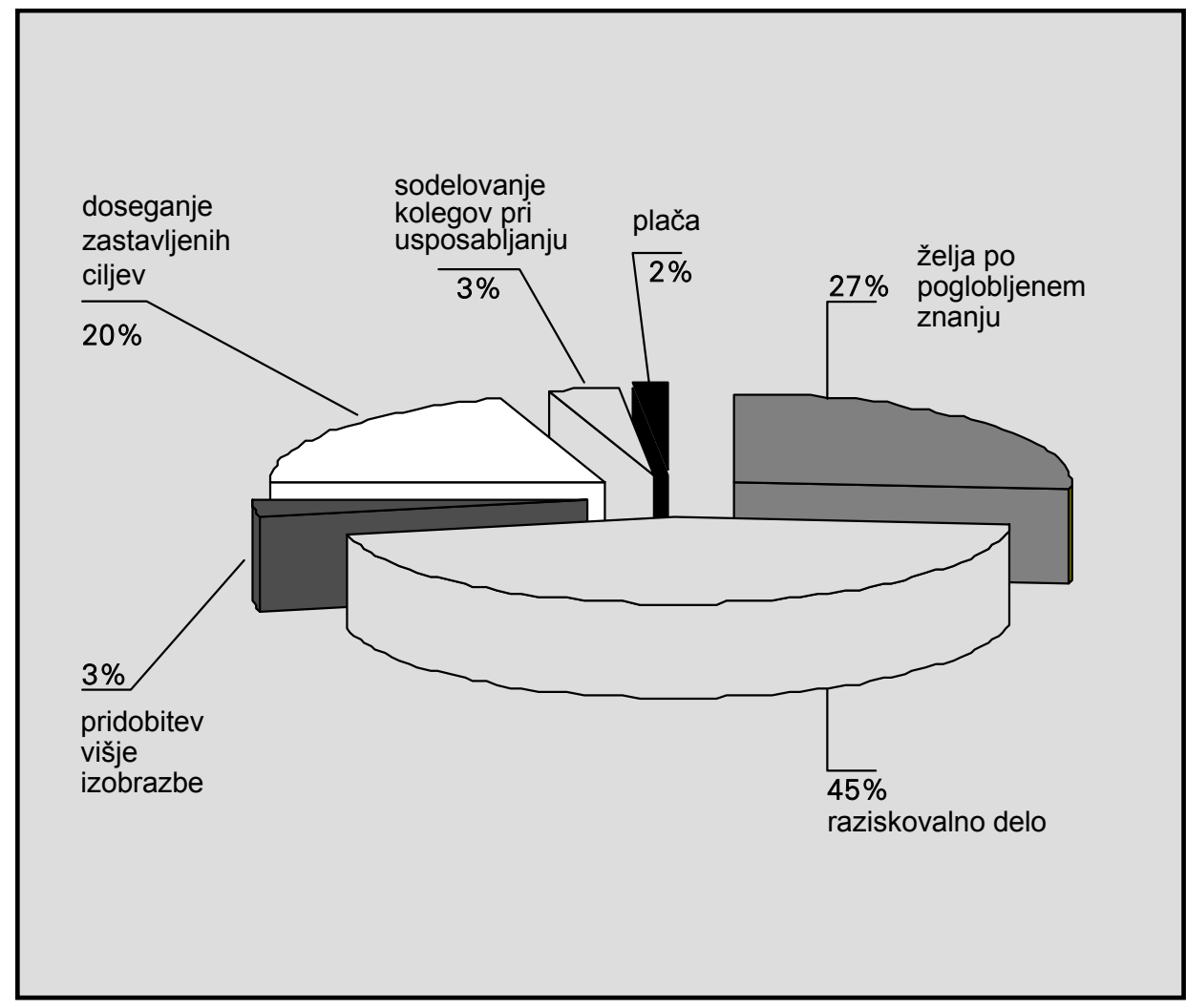

Vir: anketa, april 2006

Kar $45 \%$ mladim raziskovalcem je bilo raziskovalno delo največji motiv pri odločitvi za študij kot mladi raziskovalec, 27\% pa si želi poglobljenega znanja.

Podobno vprašanje je bilo $v$ intervjuju zastavljeno mentorjem. Zanimalo nas je, kakšen je po njihovem mnenju razlog, da se mladi raziskovalci odločajo za to vrsto študija. Odgovori so prikazani na sliki 2. 


\section{Slika 2: Razlog za študij kot mladi raziskovalec po mnenju mentorjev}

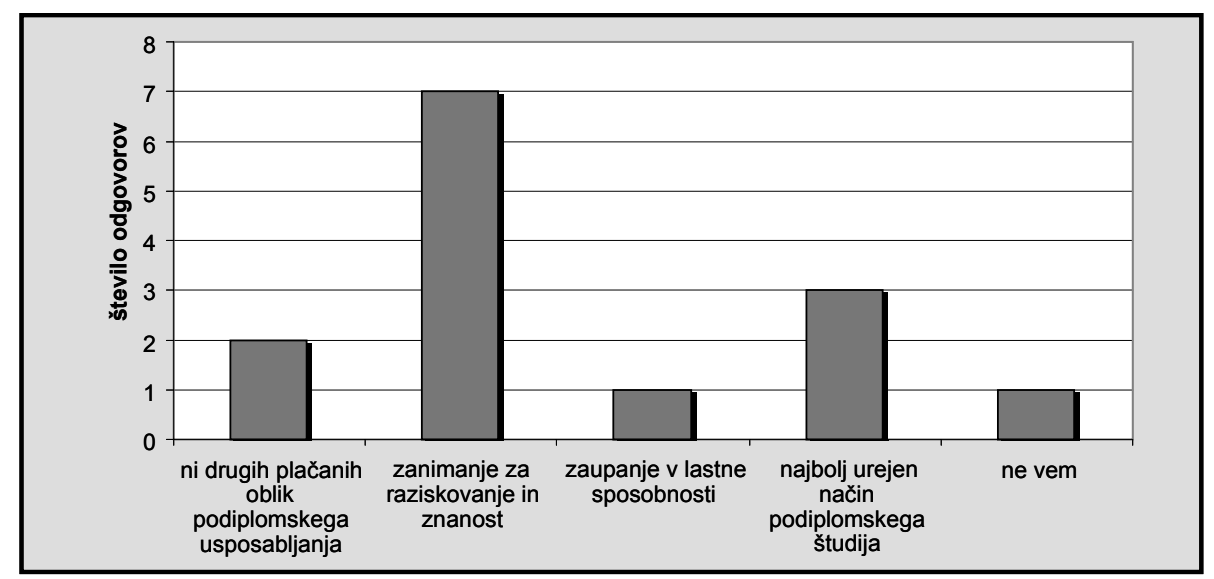

Vir: intervju, april 2006

Tudi mentorji so kot najpogostejši razlog izbrali zanimanje mladih raziskovalcev za raziskovanje in razvoj. Mentorji so tudi menili, da ta oblika usposabljanja slovi kot najbolj urejen način podiplomskega študija.

Na vprašanje, zastavljeno mladim raziskovalcem, kdo oziroma kaj je najbolj vplivalo na njihovo odločitev za študij kot mladi raziskovalec, ki se usposablja na raziskovalni organizaciji, so bili dobljeni naslednji odgovori predstavljeni na sliki 3.

Slika 3: Največji vpliv na odločitev za študij kot mladi raziskovalec

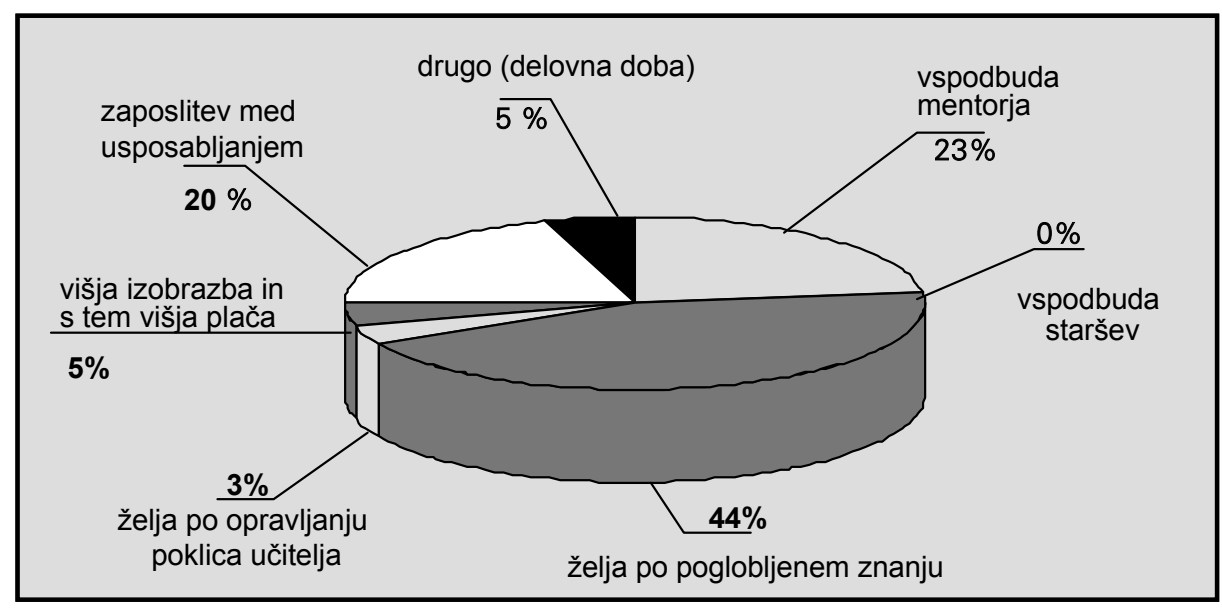

Vir: anketa, april 2006 


\section{Usposabljanje mladih raziskovalcev}

Iz slike 3 je razvidno, da je bila želja po poglobljenem znanju navečji vpliv za odločitev mladih raziskovalcev za tovrstni študij; tako je odgovorilo kar $44 \%$ vprašanih mladih raziskovalcev, s 23 odstotki sledi odgovor, da je na njihovo odločitev najbolj vplivala spodbuda mentorja.

Kar petini mladih raziskovalcev pa je ključnega pomena zaposlitev $\vee$ času usposabljanja in z zaposlitvijo povezane "ugodnosti" (organizacija plača šolnino, službena potovanja - mednarodne konference, poletne šole, vzpostavljanje stikov z mednarodno priznanimi strokovnjaki, prejemanje plače, delovna doba ipd.). Mladi raziskovalci so $v$ času usposabljanja zaposleni na visokošolskem zavodu (fakulteti) ali na raziskovalnem inštitutu. Le na 5 odstotkov mladih raziskovalcev je najbolj vplivala pridobitev višje izobrazbe in s tem višje plače.

Naslednje vprašanje, ki je bilo zastavljeno mladim raziskovalcem, je bilo, katera se jim zdi največja slabost pri usposabljanju. Dobljena je bila naslednja struktura:

\section{Slika 4: Največa slabost pri usposabljanju}

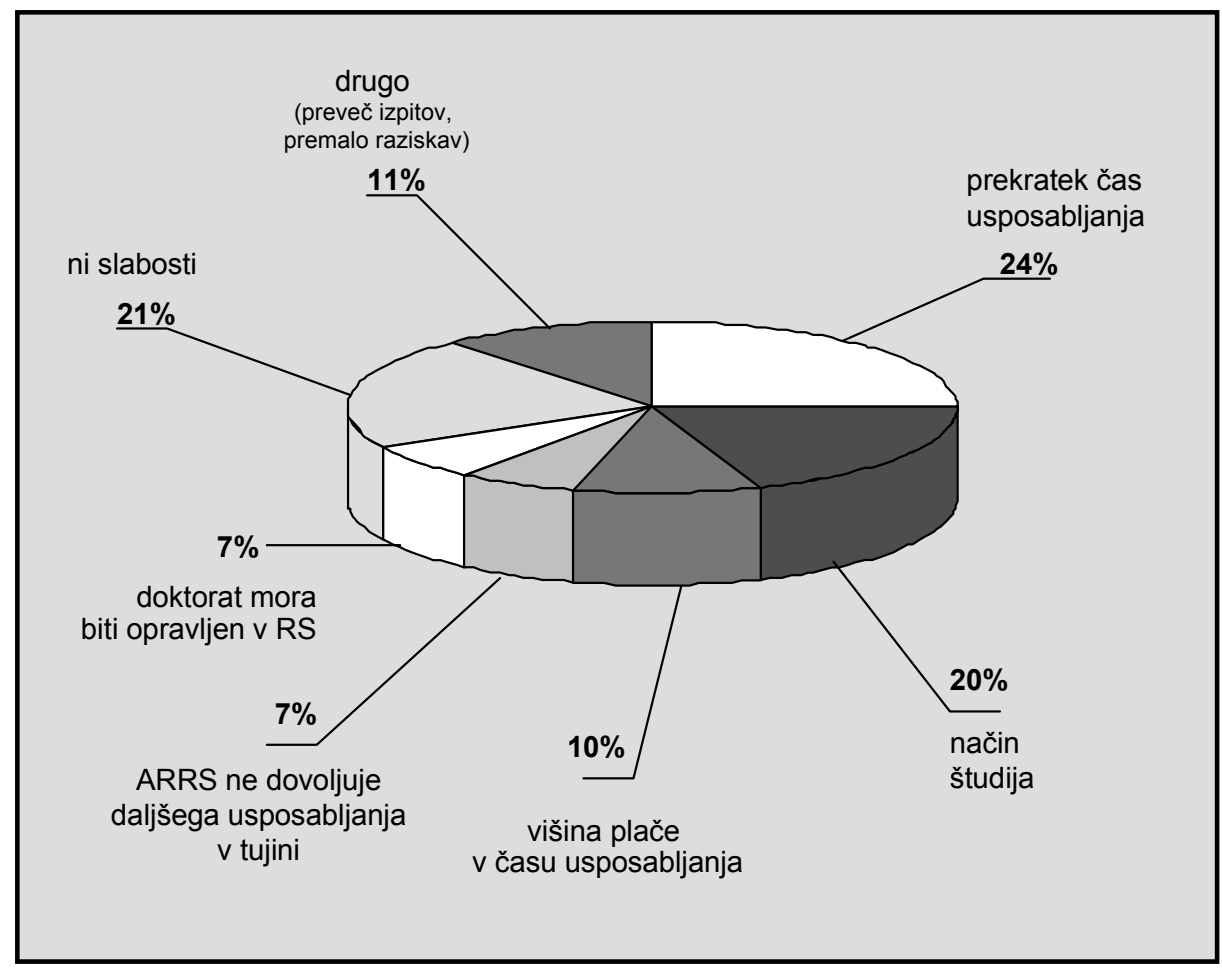

Vir: anketa, april 2006 
Kar četrtina mladih raziskovalcev meni, da je največja slabost pri študiju prekratek čas usposabljanja. ARRS financira usposabljanje mladih raziskovalcev do doktorata znanosti, in sicer do največ štiri leta in šest mesecev. Mladi raziskovalec, ki se usposablja za pridobitev doktorata znanosti, lahko usposabljanje zaključi s pridobitvijo magisterija. ARRS $v$ tem primeru financira usposabljanje do največ dve leti in šest mesecev, vendar po tem mladi raziskovalec nima več pravice do nadaljnjega financiranja. Mladim raziskovalcem s področja medicine, ki poleg doktorskega usposabljanja istočasno opravljajo tudi pripravništvo, sekundariat ali specializacijo, lahko ARRS podaljša čas raziskovalnega usposabljanja tako, da se njihov program z zagovorom doktorata zaključi v devetih letih od vstopa $\vee$ program mladih raziskovalcev. $\vee$ teh primerih polno financira program največ štiri leta in šest mesecev, tako da se financiranje po posameznih letih razporedi, glede na čas izvajanja programa in že pridobljena javno finančna sredstva iz naslova pripravništva, sekundariata ali specializacije.

Mentorji so na vprašanje, kaj bi morali na ARRS najprej spremeniti glede usposabljanja mladih raziskovalcev, oziroma kaj je največja slabost obstoječega načina usposabljanja, odgovorili naslednje:

\section{Slika 5: Potrebna sprememba na ARRS po mnenju mentorjev}

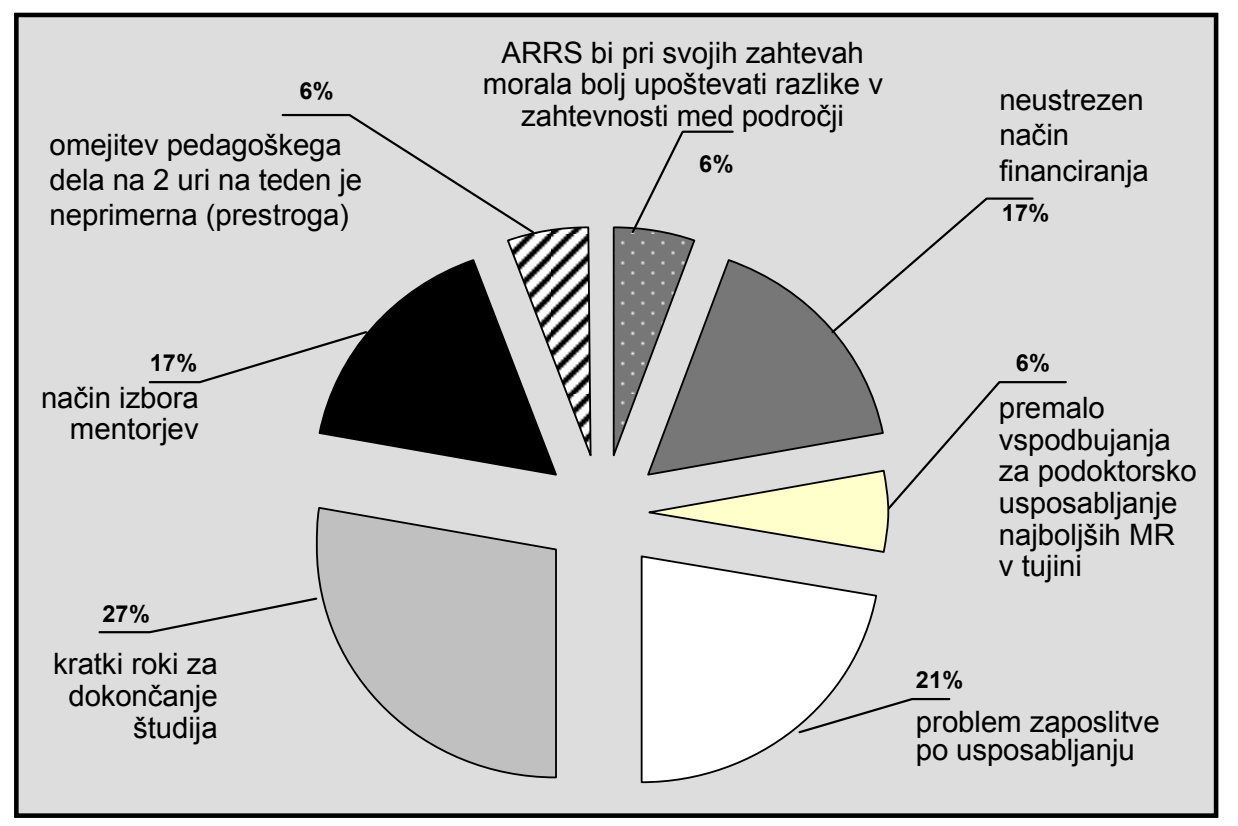

Vir: intervju, april 2006 
Iz gornjega prikaza (Slika 5) je tudi po mnenju mentorjev, kar 27\% jih je menilo tako, da so prekratki roki za dokončanje študija največja slabost obstoječega načina usposabljanja in financiranja mladih raziskovalcev. Dobra petina mentorjev pa je na prvo mesto postavila problem zaposlitve mladega raziskovalca po končanem usposabljanju. $\mathrm{Na}$ tretje in četrto mesto so mentorji kot slabost uvrstili neustrezen način financiranja in način izbora mentorjev.

Več kot polovico mladih raziskovalcev, kar 31, to je $51 \%$ anketirancev, v času usposabljanja najbolj skrbi, da ne bi pravočasno našla ustrezne zaposlitve. Njihova zaskrbljenost je razvidna iz naslednje slike:

\section{Slika 6: Največja zaskrbljenost v času študija}

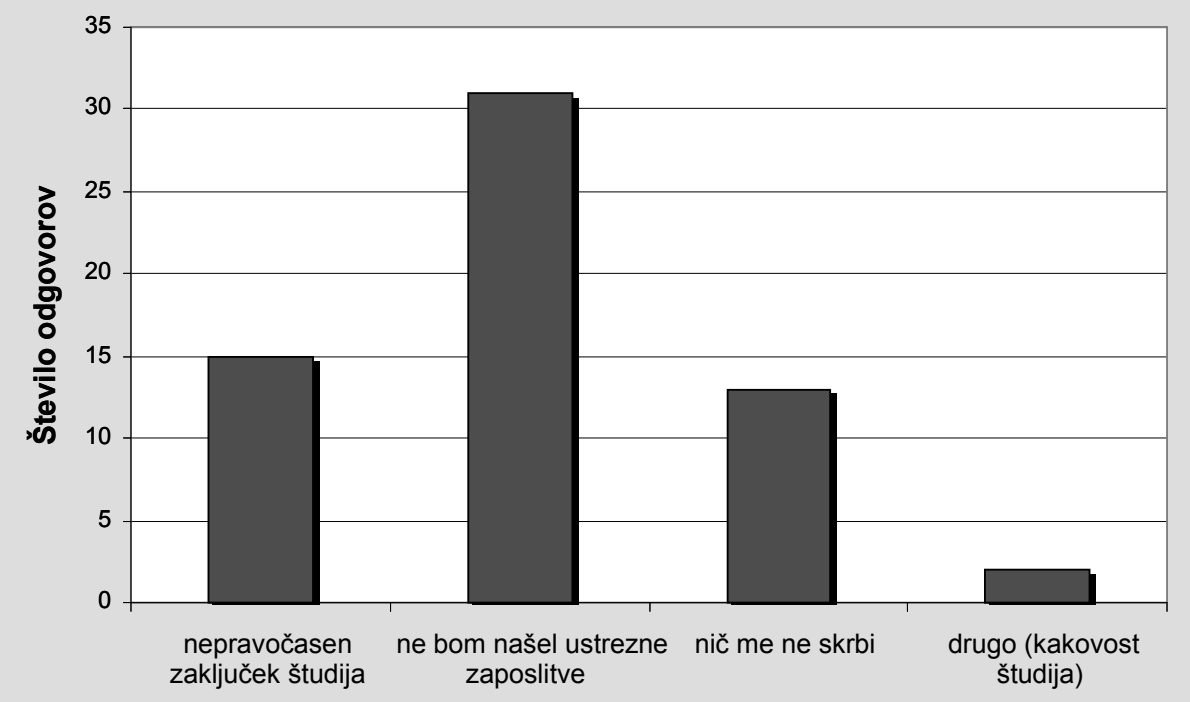

Vir: anketa, april 2006

Zanimalo nas je, kaj mentorji menijo, kaj mlade raziskovalce $v$ času študija najbolj skrbi. Odgovorili so naslednje: 


\section{Slika 7: Največja zaskrbljenost v času študija po mnenju mentorjev}

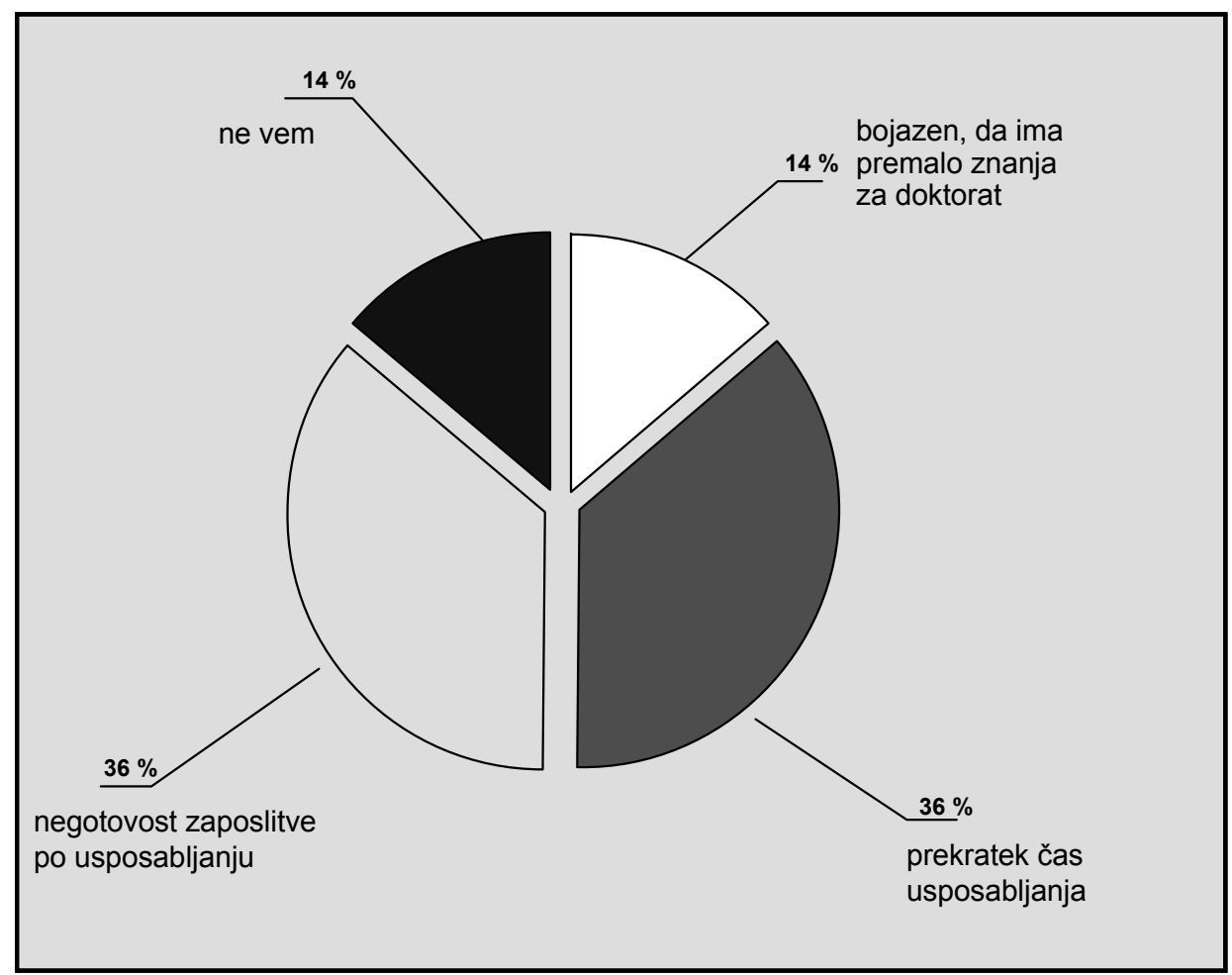

Vir: intervju, april 2006

Mentorjev, ki so menili, da je največja zaskrbljenost mladih raziskovalcev $v$ času študija negotovost zaposlitve po usposabljanju, je bilo 36\%, prav toliko pa jih je menilo, da mlade raziskovalce najbolj skrbi prekratek čas usposabljanja.

Najbolj moteč faktor za mlade raziskovalce je neustrezna vsebina študija. Na drugem mestu so bili naslednji štirje odgovori:

- $\quad$ prekratek čas usposabljanja

- $\quad$ premalo pomoči mentorja

- $\quad$ premalo pomoči pri raziskovalnem delu

- $\quad$ premalo zanimanja fakultet za mlade raziskovalce.

Iz odgovorov (Slika 8) lahko sklepamo, da si mladi raziskovalci želijo predvsem veliko pomoči mentorja, tako pri usposabljanju kot tudi pri raziskovalnem delu. 
Tanja Cvek

Usposabljanje mladih raziskovalcev

Slika 8: Najbolj moteče v času študija

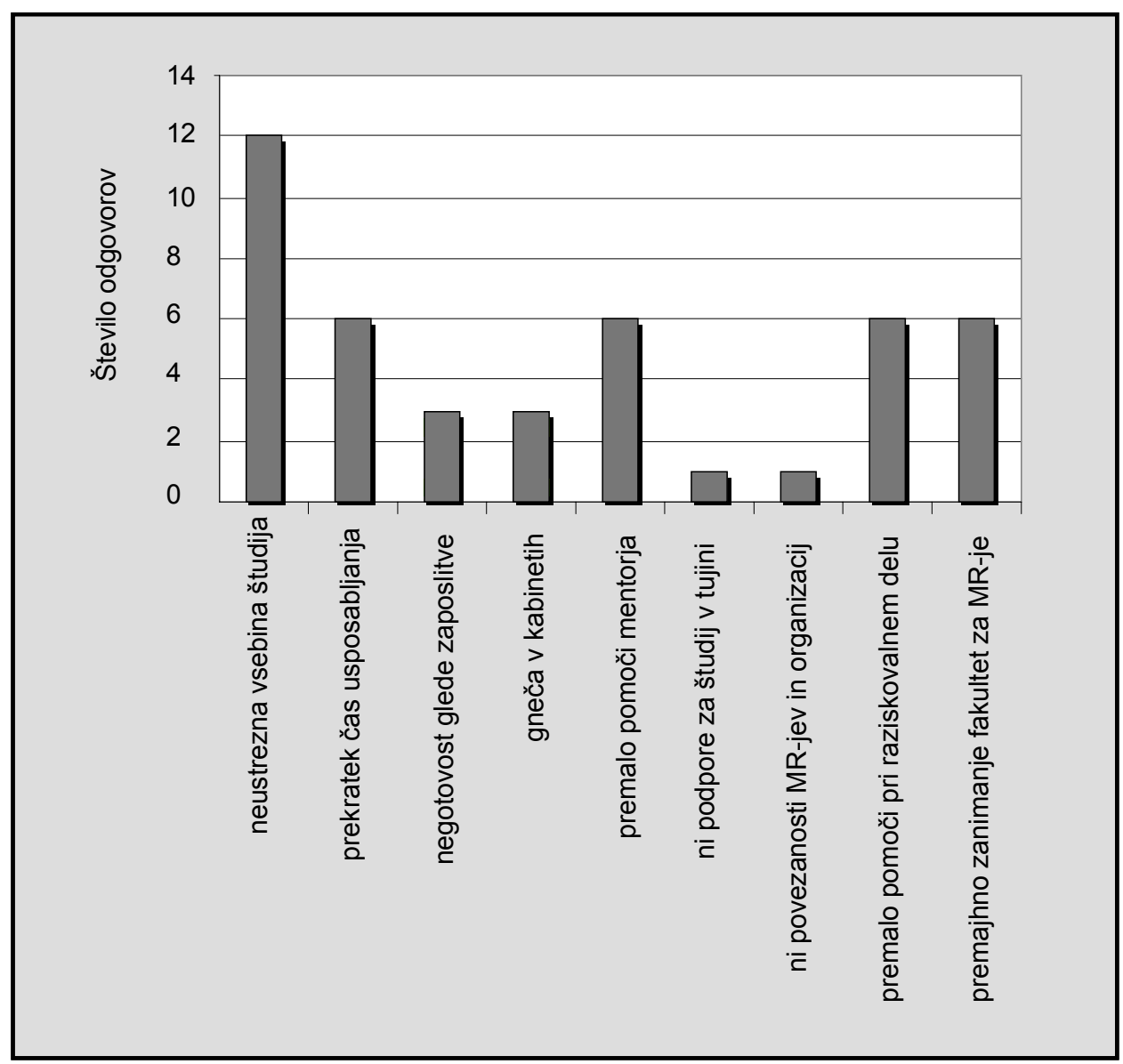

Vir: anketa, april 2006

Mladim raziskovalcem je bilo zastavljeno vprašanje, na kakšnem delovnem mestu bi se po zaključenem usposabljanju želeli zaposliti. Odgovori (Slika 9) so bili zelo pestri.

Največ mladih raziskovalcev, kar 38 odstotkov vprašanih, bi se želelo zaposliti kot raziskovalec na inštitutu, z 31 odstotki jim sledijo tisti, ki bi želeli postati visokošolski učitelji. Najnižji odstotki so bili namenjeni vodstvenim nalogam (direktor, vodja proizvodnje), prav nihče pa se ne bi želel zaposliti kot učitelj na srednji šoli. 
Tanja Cvek

Usposabljanje mladih raziskovalcev

Slika 9: Želeno delovno mesto (mladi raziskovalci)

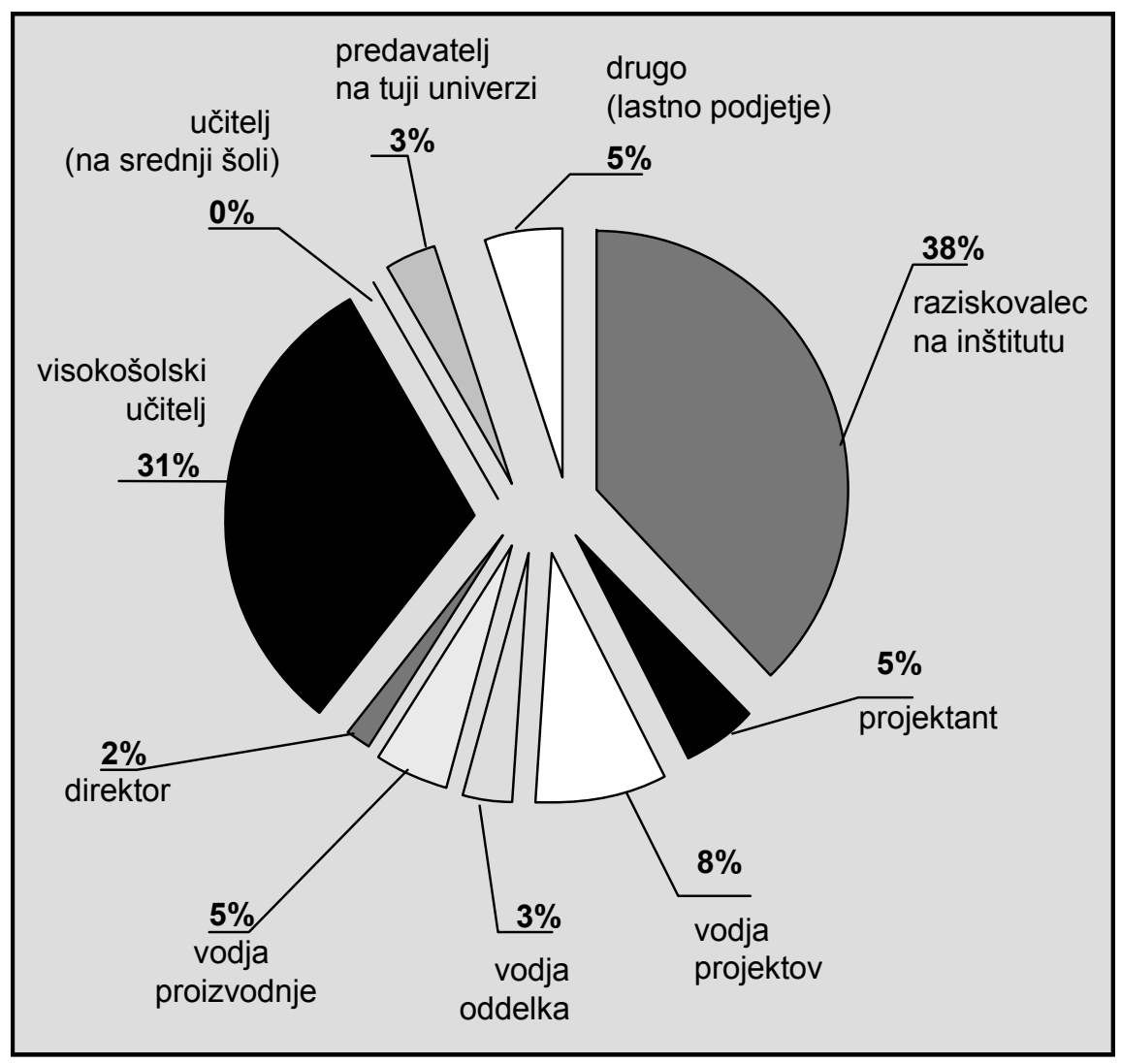

Vir: anketa, april 2006

Eno zadnjih vprašanj, namenjenih mladim raziskovalcem je bilo, od koga pričakujejo največ pomoči pri iskanju zaposlitve po uspešno zaključenem študiju. Odgovori (Slika 10) so še enkrat se potrdili trditev, da mladi raziskovalci mentorjem močno zaupajo. Kar 29 mladih raziskovalcev od 63 vprašanih, kar je skoraj polovica, jih namreč pričakuje pomoč pri iskanju zaposlitve ravno od svojega mentorja na podiplomskem študiju. Skoraj enak odstotek pa se jih zaveda, da se bodo pri iskanju zaposlitve morali $v$ največji meri zanesti kar nase. 
Tanja Cvek

Usposabljanje mladih raziskovalcev

Slika 10: Pričakovana pomoč pri iskanju zaposlitve

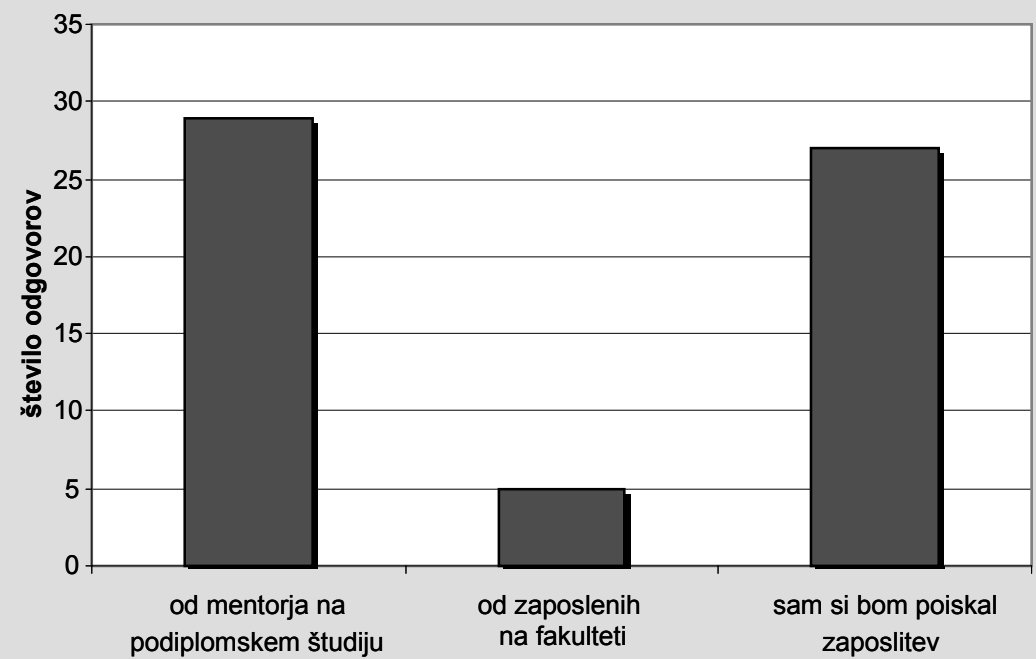

Vir: anketa, april 2006

Večina mladih raziskovalcev - doktorjev znanosti - po končanem usposabljanju ostane oziroma se zaposli na fakultetah ali raziskovalnih inštitutih. Vendar so raziskovalna mesta $\vee$ akademskih ustanovah že precej zapolnjena, zato lahko pričakujemo povečanje brezposelnosti, težave pri iskanju ustrezne zaposlitve ter odhajanje mladih strokovnjakov $v$ tujino. Tu bi bilo potrebno resno opozoriti na sistemsko podpiranje zaposlovanja novih strokovnjakov in uporabe njihovega znanja v Sloveniji.

Tudi mentorjem je bilo $v$ intervjuju postavljeno podobno vprašanje - od koga po nijhovem mnenju mladi raziskovalci pričakujejo največ pomoči pri iskanju zaposlitve po uspešno zaključenem študiju.

Najpogostejši odgovor mentorjev (Slika 11) se sklada s pričakovanji mladih raziskovalcev. Tudi mentorji predvidevajo, da mladi raziskovalci prav od njih pričakujejo največ pomoči pri iskanju bodoče zaposlitve. 
Slika 11: Pričakovana pomoč pri iskanju zaposlitve po mnenju mentorjev

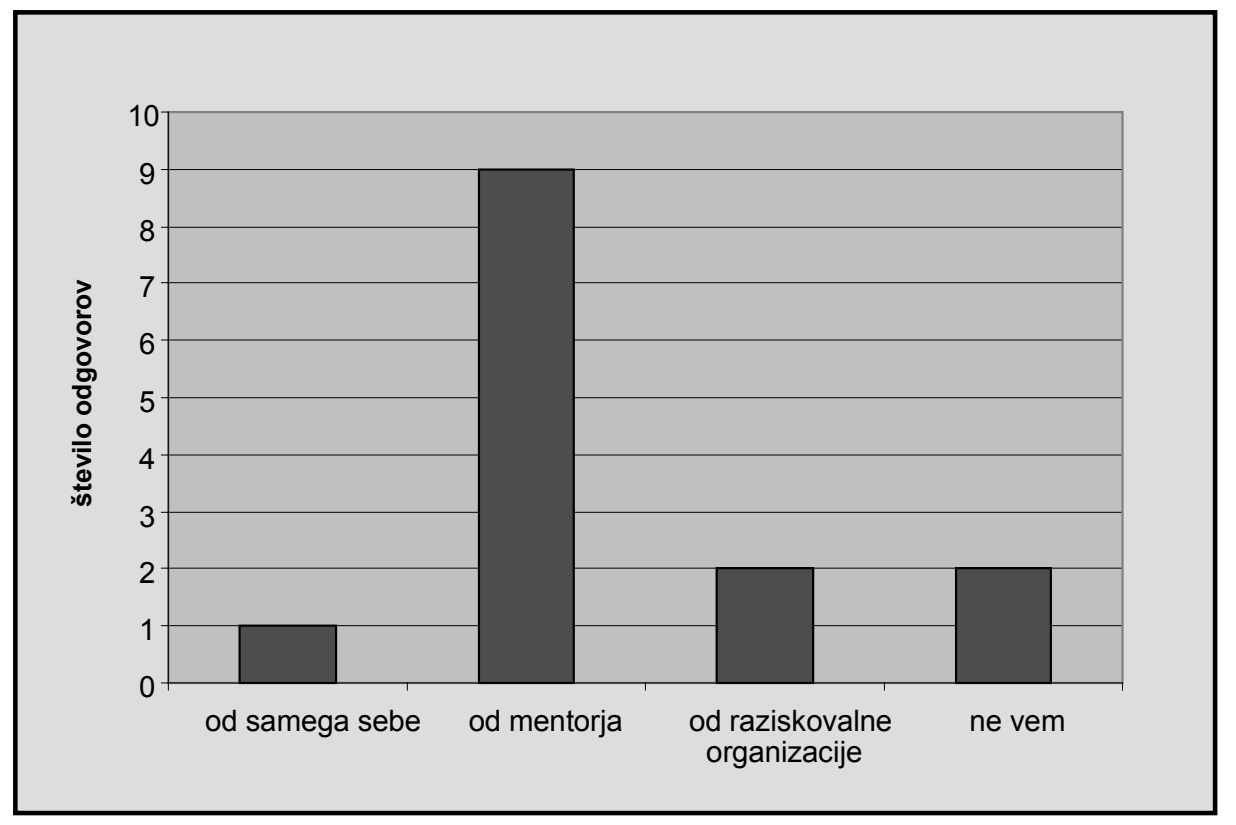

Vir: intervju, april 2006

\section{Sklepne ugotovitve}

Projekt 2000 mladih raziskovalcev teče že od leta 1985 in je lahko nedvomno ocenjen kot strateška odločitev, katere namen je bil, v razmeroma kratkem času pridobiti visoko izobražene kadre za potrebe gospodarstva ter obnoviti in pomladiti kadre $\mathrm{v}$ raziskovalnih organizacijah in visokošolskih zavodih.

Strnjena ugotovitev opravljene analize bi lahko bila naslednja:

- Mladi raziskovalci imajo močno željo po znanstveno raziskovalnem delu, prav zato se odločajo za to vrsto usposabljanja.

- Največjo pomanjkljivost vidijo mladi raziskovalci v prekratkem času usposabljanja. Zaskrbljeni so tudi zaradi 38. člena Pravilnika o usposabljanju in financiranju mladih raziskovalcev $v$ raziskovalnih organizacijah, ki pravi: "če namen in cilj programa usposabljanja (zagovor doktorata) nista dosežena $\vee$ pogodbenem roku oziroma roku podaljšanem za 6 mesecev 


\section{Usposabljanje mladih raziskovalcev}

brez zagotovila finančnih sredstev agencije, sta izvajalec in mladi raziskovalec dolžna vrniti vsak po $5 \%$ izplačanih sredstev."

- Predvsem si mladi raziskovalci želijo boljših možnosti za zaposlitev po končanem usposabljanju, saj so zaradi negotovosti glede zaposlitve trenutno zelo zaskrbljeni.

- Mladi raziskovalci bi si želeli več pomoči mentorjev, tako pri podiplomskem študiju, ko tudi pri raziskovalnem delu.

Opravljena analiza da slutiti, da so mladi raziskovalci premalo pripravljeni na samostojno delo, samoiniciativnost, nekateri imajo morda premalo samozavesti. Ti potrebujejo spodbude, ki jim omogočajo doživljati zadovoljstvo ob napredovanju $v$ procesu prenosa znanja $z$ mentorja na mladega raziskovalca in več pohvale, kot pozitivne povratne informacije. Temeljna zakonitost pri povezavi mentor - mladi raziskovalec je naslednja:

- mladi raziskovalec mora videti zastavljeni cilj podiplomskega študija,

- mentor pa mora obvladati veščine učenja, prenosa znanja na mladega raziskovalca.

Projekt 2000 mladih raziskovalcev lahko z več vidikov ocenjujemo kot uspešnega in skladnega z raziskovalno politiko razvitih držav. Vprašanje pa je, če je sedanji način usposabljanja mladih raziskovalcev tudi najbolj ustrezen.

Problematično je tudi obdobje po končanem usposabljanju mladih raziskovalcev. Pojavljajo se podobne težave, kot jih imajo $v$ drugih državah. Na eni strani se pojavlja problem pridobivanja sredstev za mlade raziskovalce, ki ostanejo zaposleni za obnovo raziskovalnega kadra na raziskovalnih organizacijah, na drugi strani pa omejene sposobnosti gospodarstva, da sprejme večje število raziskovalno usposobljenih mladih ljudi, ter usmeritev gospodarstva h kratkoročnim rešitvam, ki prav tako zmanjšuje možnosti zaposlovanja mladih strokovnjakov.

Mladi raziskovalci $\vee$ Evropski uniji (EU) potrebujejo stabilne delovne razmere. Če hoče EU postati najbolj konkurenčna na znanju temelječa družba, mora poskrbeti za učinkovitejšo podporo mladim raziskovalcem. Zagotoviti jim mora zlasti okolje, da po pol leta sredi raziskave ne bodo več ostali na cesti. Da bodo ostali $\vee$ EU in ne več množično odhajali predvsem $\vee$ ZDA, jim je treba na znanstvenih inštitutih zagotoviti enake možnosti za dolgoročno raziskovalne in povezave $v$ okviru celotne EU, kot jih imajo tisti strokovnjaki, ki se zaposlijo $v$ 
zasebnih podjetjih. Mladi raziskovalci so prepričani, da imajo tisti, ki so se zaposlili v industrijskih podjetjih, boljšo plačo kot tisti, ki so zaposleni v javnih zavodih. Vsekakor pa zatrjujejo, da plača ni glavno merilo, saj uživajo $\vee$ raziskavah, ki jih delajo. Negotovost zaposlitve jim pomeni velik problem. Prav ta negotovost je problem mladih raziskovalcev povsod $\vee$ EU.

$\mathrm{Da}$ bi mladim znanstvenikom zagotovili boljše in predvsem enake možnosti in pravice $v$ vsej EU, je Evropska komisija pripravila Evropsko listino za raziskovalce, Kodeks ravnanja pri zaposlovanju raziskovalcev ter Pravilnik o naboru raziskovalcev, ki so jih v okviru ministrskega sveta aprila 2005 potrdile tudi države članice. Evropska komisija je $\vee$ Bruslju sprejela evropsko listino in kodeks ravnanja za njihov nabor, z željo področje raziskav narediti bolj privlačno, saj gre za enega ključnih elementov $v$ strategiji spodbujanja rasti gospodarstva in zaposlovanja. Dokumenti zagotavljajo znanstvenim organizacijam, ki jih izvajajo, pomembno konkurenčno prednost, saj predpisujejo minimalne pogoje za plačilo znanstvenikov, prepovedujejo diskriminacijo mladih raziskovalcev na podlagi izkušenj in neskončno podaljševanje pogodb o zaposlitvi za nekaj mesecev.

Tehnološka politika, ki izhaja iz razvoja znanosti, v svetu že nekaj časa ni usmerjena samo $k$ ustvarjanju novih tehnologij, temveč tudi $k$ povečevanju zmožnosti obstoječih. Poudarek je na izgradnji infrastrukture in širitvi sposobnosti, da se obstoječe in nove tehnologije širijo in uporabijo. Usposabljanje mladih raziskovalcev omogoča razširitev znanstvenega znanja in obenem prenos tega znanja $v$ industrijo.

Tanja Cvek se je po končani Srednji upravno administrativni šoli leta 1986 zaposlila v kadrovski službi Beogradske banke v Ljubljani. Zaradi stečajnega postopka banke se je zaposlila na Inštitutu za matematiko, fiziko in mehaniko v Ljubljani kot vodja pisarne. Leta 2000 je diplomirala na Visoki upravni šoli ter pridobila strokovni naslov diplomirana upravna organizatorka, sedaj pa na Fakulteti za upravo UL zaključuje podiplomski magistrski študij. Od junija 2007 je zaposlena na Inštitutu za računovodstvo kot vodja projektov. 


\section{Tanja Cvek \\ Usposabljanje mladih raziskovalcev}

\section{Literatura in viri}

- Kocbek, D. (2005): Da z mladimi znanstveniki v državah EU ne bi več pometali. V: Delo, 15.12.2005, stran 17 .

- Pečlin, S. (1993): Mladi raziskovalci, poročilo, Ministrstvo za znanost in tehnologijo, Ljubljana.

- $\quad$ Priporočilo komisije z dne 11. marca 2005 o Evropski listini za raziskovalce ter o Kodeksu ravnanja pri zaposlovanju raziskovalcev, Uradni list EU, 22.3.2005, št. priporočila 2005/251/ES.

- Kolektivna pogodba za raziskovalno dejavnost (Uradni list RS, št. 45/92 in spremembe).

- $\quad$ Pravilnik o sofinanciranju programa znanost mladini (Uradni list RS, št. 50/06).

- $\quad$ Pravilnik o usposabljanju in financiranju mladih raziskovalcev $v$ raziskovalnih organizacijah (Uradni list RS, št. 49/05).

- Navodilo o porabi sredstev za usposabljanje mladih raziskovalcev - januar 2006 (ARRS, 22.2.2006).

- $\quad$ Sklep o višini subvencije za usposabljanje mladih raziskovalcev - januar 2006 (ARRS, 24.1.2006).

- Usmeritve Ministrstva za visoko šolstvo, znanost in tehnologijo za dodelitev proračunskih sredstev za sofinanciranje programa znanost mladini v letih 2006 in 2007 (MVZT, 19.5.2006).

- Usmeritve Ministrstva za visoko šolstvo, znanost in tehnologijo za razdelitev proračunskih sredstev namenjenih financiranju usposabljanja mladih raziskovalcev v raziskovalnih organizacijah v letu 2006 in v letu 2007 (MVZT, 13.4.2006).

- Metodologija ocenjevanja prijav za sofinanciranje programa znanost mladini s kvantitativnimi merili in načinom določanja višine sredstev za sofinanciranje posameznega programa v letih 2006 in 2007 (ARRS, 19.5.2006).

- Metodologija postopka ocenjevanja kandidatov za mentorje mladih raziskovalcev $v$ letih 2006 in 2007 (ARRS, 13.4.2006).

- Evropski mobilnostni portal za raziskovalce

"http://europa.eu.int/eracareers/index_en.cfm?lg=SL", 3.6.2006.

- Javna agencija za raziskovalno dejavnost Republike Slovenije, "http://www.arrs.gov.si/sl/mr/", 5.6.2006.

- Ministrstvo za visoko šolstvo, znanost in tehnologijo, "http://www.mvzt.si/index.php?id=255", 1.6.2006. 


\section{SUMMARY}

\section{TRAINING OF YOUNG RESEARCHERS}

One of the tasks of the Slovenian Research Agency (ARRS) is to take care of the execution of the young researchers programme called 2000 Young Researchers Project, which is carried out in accordance with the National Research and Development Programme and the annual policy of the Ministry of Higher Education, Science and Technology. The programme has substantially contributed to a rise in quality of research and to staff rejuvenation within research groups. Until 2006, 5,347 young researchers entered the programme.

The main features of the young researchers programme are that young researchers participate in research work in basic research and applied research projects alongside their postgraduate studies, and that they have a fixed-duration employment. The ARRS provides funds for their salaries, social contributions, and material and non-material expenses for their research work and postgraduate studies. The funds for the training of young researchers are given for a fixed period of time, namely for a maximum of four and a half years for a doctorate. Each year, from 200 to 250 young researchers complete their training.

National research programmes have always placed emphasis on the education of research staff as a complementary goal of research, and in relation to that emphasized that "because Slovenia is small and relatively undeveloped it cannot produce all of the knowledge it needs itself, for this reason taking care of the dissemination of knowledge produced abroad is especially important, which by no means implies that it would be more appropriate for Slovenia to neglect basic research in favour of the transfer of knowledge, since producing new knowledge is a prerequisite for a successful transfer of knowledge".

The aim of the research was to present the training as seen by young researchers. We were mostly interested in what they were dissatisfied with, what concerned them most, and what were, in their opinion, the advantages and disadvantages of this type of training.

The concept of training young researchers in research groups has not changed over the years. Team work is expected from research groups, which is especially important in training young researchers. The mentor, the research group leader and the young researcher take the responsibility 
Tanja Cvek

Usposabljanje mladih raziskovalcev

for carrying out the training programme. The ARRS concludes a contract for a young researcher's training with the provider of the training (a highereducation organization or a research institute) and with the young researcher. Leaders and mentors in research groups young researchers are trained in should also take the opportunities of sending young researchers to short-term training programmes at universities and institutes abroad, which not only adds additional quality to the training of the young researcher, but also makes the research group more open to the world.

Young researchers often participate in various discussions about the training pointing out inappropriate solutions regarding the placement of young researchers at universities and in research organizations, the shortcomings of the training itself, and problems on completion of the training.

To determine if young researchers are satisfied with their training or not, a survey was carried out among the young researchers from three higher-education institutions and two research institutes; interviews with some of the mentors of young researchers were also conducted.

Young researchers who complete their training remain employed in research organizations to renew research staff or in higher-education organizations to renew research-teaching staff. Some of them enter organizations in the economy, others find employment in state administration.

One of the main reasons for conducting the survey was to find out what the shortcomings of the training of young researchers were. We also wanted to know what made them decide on this type of studies. Many of the mentors believe that this form of training has a reputation as the most well-organized form of postgraduate studies. According to $44 \%$ of the interviewed young researchers, a desire for a deeper knowledge was the biggest influence on their decision for this type of studies. To no less than one fifth of the young researchers employment for the duration of the training and the "perks" that go with employment (the tuition fees paid by the organization, business trips, international conferences, summer schools, establishing links with internationally recognized experts, receiving a salary, acquiring years of service etc.) was of key importance. To only $5 \%$ of the young researchers the biggest influence on their decision was acquiring higher qualifications and consequently a higher salary. No less than a quarter of the young researchers consider that the time for the training is too short and see that as the greatest shortcoming of these studies. The ARRS finances the training of young researchers until they acquire a doctorate, namely for a maximum of four and a half years. A 
young researcher training to acquire a doctorate can conclude his/her training by getting a master's degree. In such a case the ARRS finances his/her training for a maximum of two and a half years, after which the young researcher no longer has the right to further financing. The ARRS may extend the period of research training for young researchers in the medical field who alongside the doctorate training do internship, residency or specialization; their programme ends with a defence of the doctorate in nine years after entering the young researchers programme. In these cases the ARRS provides full financing of the programme for a maximum of four and a half years - the financing being distributed over individual years depending on the duration of the programme and on the already acquired public finances for internship, residency or specialization.

In mentors' opinion, too, no less than $27 \%$ of them thought so, the period for the completion of the studies is too short. Over a fifth of the mentors points out that finding employment for a young researcher on completion of the training is the main problem, which is followed by two other shortcomings: an inappropriate way of financing and of selecting mentors. During the training over half of the young researchers, no less than 31 , which is $51 \%$ of the respondents, worry most about finding appropriate employment in time. The most disturbing factor for them is inappropriate contents of the studies. Young researchers want above all a great deal of help from their mentor with their training as well as with their research work and finding employment. In fact, no less than 29 young researchers, out of the 63 interviewed, expect to get help finding employment from their postgraduate mentor. An almost exactly the same percentage of them is aware that they will have to depend mostly on themselves to find employment. The majority of young researchers, 38\% of the interviewed, would like to work as researchers at institutes followed by the $31 \%$ of those who would like to work as university teachers. Managing positions got the lowest percentage (directors, production managers), and no-one would like to work as a secondary school teacher.

The majority of young researchers - with doctorates - on completion of the training stay at, or rather find employment at faculties or in research institutes. However, research places in academic institutions are already quite filled, so an increase in unemployment, difficulties in finding appropriate employment, and young experts going abroad is all to be expected. We should give a serious warning that the employment of young experts and the use of their knowledge in Slovenia should receive 
systemic support. The summary of the analysis made could be as follows: young researchers have a strong desire for scientific research work; this is the reason why they choose this type of training. They consider that the time for the training is too short and see that as the greatest shortcoming; they want mostly better employment opportunities on completion of the training since uncertainty about employment worries them a great deal. They want more help from their mentors with their postgraduate studies as well as with their research work. The analysis carried out leads us to believe that young researchers are not prepared enough for independent work, lack self-initiative, some of them maybe even self-confidence. These young researchers would need encouragement to help them experience satisfaction on making progress in the process of the transfer of knowledge from a mentor to a young researcher, and plenty of praise as positive feedback information.

Young researchers in the European Union (EU) need stable working conditions. If the EU wants to become the most competitive knowledgebased society, it should make sure that young researchers get a more effective support. Above all, it should provide an environment in which they could no longer become unemployed half a year after the research. Young researchers should be provided with equal opportunities for longterm research at science institutes and with links within the whole of the $E U$, just as the experts employed in private companies are, in order that they would stay in the EU instead of leaving in great numbers mainly for the USA. 